\title{
Phytochemical Analysis and Anti-cancer Investigation of Boswellia Serrata Bioactive Constituents In Vitro
}

\author{
Hanaa H Ahmed ${ }^{1 *}$, Ahmed A Abd-Rabou ${ }^{1}$, Amal Z Hassan ${ }^{2}$, Soheir E Kotob ${ }^{1}$
}

\begin{abstract}
Cancer is a major health obstacle around the world, with hepatocellular carcinoma (HCC) and colorectal cancer (CRC) as major causes of morbidity and mortality. Nowadays, there isgrowing interest in the therapeutic use of natural products for $\mathrm{HCC}$ and CRC, owing to the anticancer activity of their bioactive constituents. Boswellia serrata oleo gum resin has long been used in Ayurvedic and traditional Chinese medicine to alleviate a variety of health problems such as inflammatory and arthritic diseases. The current study aimed to identify and explore the in vitro anticancer effect of $B$. Serrata bioactive constituents on HepG2 and HCT 116 cell lines. Phytochemical analysis of volatile oils of $B$. Serrata oleo gum resin was carried out using gas chromatographymass spectrometry (GC/MS). Oleo-gum-resin of $B$. Serrata was then successively extracted with petroleum ether (extract 1) and methanol (extract 2). Gas-liquid chromatography (GLC) analysis of the lipoidal matter was also performed. In addition, a methanol extract of $B$. Serrata oleo gum resin was phytochemically studied using column chromatography (CC) and thin layer chromatography (TLC) to obtain four fractions (I, II, III and IV). Sephadex columns were used to isolate $\beta$-boswellic acid and identification of the pure compound was done using UV, mass spectra, ${ }^{1} \mathrm{H}$ NMR and ${ }^{13} \mathrm{C}$ NMR analysis. Total extracts, fractions and volatile oils of $B$. Serrata oleo-gum resin were subsequently applied to HCC cells (HepG2 cell line) and CRC cells (HCT 116 cell line) to assess their cytotoxic effects. GLC analysis of the lipoidal matter resulted in identification of tricosane $\mathbf{7 5 . 3 2 \%}$ ) as a major compound with the presence of cholesterol, stigmasterol and $\beta$-sitosterol. Twenty two fatty acids were identified of which saturated fatty acids represented $25.6 \%$ and unsaturated fatty acids $74.4 \%$ of the total saponifiable fraction. GC/MS analysis of three chromatographic fractions (I,II and III) of B. Serrata oleo gum resin revealed the presence of pent-2-ene-1,4-dione, 2-methyl- levulinic acid methyl ester, 3,5- dimethyl- 1hexane, methyl-1-methylpentadecanoate, 1,1- dimethoxy cyclohexane, 1-methoxy-4-(1-propenyl)benzene and 17a-hydroxy-17a-cyano, preg-4-en-3-one. GC/MS analysis of volatile oils of $B$. Serrata oleo gum resin revealed the presence of sabinene $(19.11 \%)$, terpinen-4-ol $(14.64 \%)$ and terpinyl acetate $(13.01 \%)$ as major constituents. The anti-cancer effect of two extracts (1 and 2) and four fractions (I, II, III and IV) as well as volatile oils of $B$. Serrata oleo gum resin on HepG2 and HCT 116 cell lines was investigated using SRB assay. Regarding HepG2 cell line, extracts 1 and 2 elicited the most pronounced cytotoxic activity with $\mathrm{IC}_{50}$ values equal 1.58 and 5.82 $\mu \mathrm{g} / \mathrm{mL}$ at $48 \mathrm{~h}$, respectively which were comparable to doxorubicin with an $\mathrm{IC}_{50}$ equal $4.68 \mu \mathrm{g} / \mathrm{mL}$ at $48 \mathrm{~h}$. With respect to HCT 116 cells, extracts 1 and 2 exhibited the most obvious cytotoxic effect; with $\mathrm{IC}_{50}$ values equal 0.12 and $6.59 \mu \mathrm{g} / \mathrm{mL}$ at $48 \mathrm{~h}$, respectively which were comparable to 5 -fluorouracil with an $\mathrm{IC}_{50}$ equal $3.43 \mu \mathrm{g} /$ $\mathrm{mL}$ at $48 \mathrm{~h}$. In conclusion, total extracts, fractions and volatile oils of $B$. Serrata oleo gum resin proved their usefulness as cytotoxic mediators against HepG2 and HCT 116 cell lines with different potentiality (extracts > fractions $>$ volatile oil). In the two studied cell lines the cytotoxic acivity of each of extract 1 and 2 was comparable to doxorubicin and 5-fluorouracil, respectively. Extensive in vivo research is warranted to explore the precise molecular mechanisms of these bioactive natural products in cytotoxicity against HCC and CRC cells.
\end{abstract}

Keywords: Boswellia serrata - phytochemical analysis - HepG2 cell line - HCT 116 cell line - cytotoxicity.

Asian Pac J Cancer Prev, 16 (16), 7179-7188

\section{Introduction}

After decades of research, cancer is still a devastating disease, responsible for roughly one quarter of worldwide deaths. It is one of the most imminent health obstacles in the developed countries; where it represents the second largest cause of mortality. Therefore, it deserves a high priority of research to combat the enormous human suffering and related health care (Rang et al., 2003).

Hepatocellular carcinoma (HCC), the major primary malignant tumor of the liver, is one of the most lifethreatening human cancers (Shahat et al., 2015) and is 
a leading cause of cancer death worldwide (Mitupatum et al., 2015). HCC is the third leading cause of cancer deaths worldwide, with prevalence 16-32 times higher in developing countries. The incidence of HCC is higher in males than in females with the male: female ratio usually averaging between 2:1(El-Seragand Rudolph, 2007). The treatment of HCC is limited because of the underlying cirrhosis and a high rate of recurrence; the cumulative 5-year survival rate is $53.4 \%$ with hepatic resection, $42.0 \%$ with local ablation therapy, and $22.6 \%$ with transcatheter arterial embolization (Tanaka and Arii, 2009). Lack of effective diagnostic tools for early detection and limited treatment options for patients with advanced HCC contribute to a dismal prognosis coupled with high mortality for this disease (Thomas et al., 2010; Bishayee, 2012). Persistent oxidative stress and unresolved inflammation are two primary driving forces behind the development and exacerbation of HCC (Kawanishi et al., 2006; Bishayee, 2012). Moreover, lingering infection with hepatitis $\mathrm{B}$ virus (HBV) and hepatitis $\mathrm{C}$ virus ( $\mathrm{HCV}$ ) represents the major risk factor for HCC (Gao et al., 2012).

In recent years, colorectal cancer (CRC) incidence has been increasing to become a major cause of morbidity and mortality worldwide from cancers, with high rates in westernized societies and increasing rates in developing countries(Schnekenburgerand Diederich, 2012). Although its etiology is multifactorial and complex, it is generally accepted that the hereditary genetic component associated with dietary habits such as low intake of fibers, proteins, fruits and vegetables as well as diets with high red and processed meat as well as fat levels are among the greatest risk factors (Watson and Collins, 2011). Endogenously formed risk factors, such as ROS, products of lipid peroxidation, nitroso compounds, and bile acids may enhance an individual's risk of developing colorectal cancer (World Cancer Research Fund and American Institute for Cancer Research, 1997).

Anticancer therapy is one of the biggest challenges in medicine, therefore, searching for highly efficient antitumor drugs remains a hot research area. At present, the treatment of cancer mainly includes surgery and chemotherapy, but the curative effects of the existing chemotherapeutic drugs are not good enough and they have numerous side effects. In recent years, the naturally occurring substances have been receiving increased attention by researchers and have been the subject of many rigorous scientific studies(Abd-Rabouet al., 2012). Natural dietary agents including fruits, vegetables, and spices have drawn a great deal of attention from both the scientific community and the general public owing to their demonstrated ability to suppress cancers. These dietary agents are believed to suppress the inflammatory processes that lead to transformation, hyperproliferation, and initiation of carcinogenesis. Their potent effects may ultimately suppress the final steps of carcinogenesis as well, namely angiogenesis and metastasis (Aggarwal and Shishodia, 2006).

Boswellia species (Burseraceae), which are trees native to Ethiopia, Somalia, India, and Arabic peninsula, produce a gum resin that is known as olibanum (frankincense). This gum resin has long been used in Ayurvedic and traditional Chinese medicine to treat a variety of health aspects (Ni et al., 2012) such as inflammatory and arthritic diseases (Liu et al., 2002). The search for the active principles of the resin resulted in the isolation of boswellic acids that belong to ursane- and oleanane-type pentacyclic triterpenes (Ammon et al., 1993 and Safayhi and Sailer, 1997). These acids have also been shown to possess potential chemopreventive effects, e.g., they inhibited the growth of brain tumor (Winking et al., 2000) and meningioma cells (Park et al., 2002) as well as they induced apoptosis in human leukemia (Shao et al.,1998).

The objective of the current study was to identify and explore the anti-cancer potenial of different extracts, chromatographic fractions as well as volatile oils of the oleo-gum-resin of B. Serrate in vitro. This was achieved through identification of their bioactive constituents using chromatographic and spectroscopic means and investigation of the cytotoxic activity of these constituents against hepatocellular carcinoma (HepG2) and colon cancer (HCT 116) cell lines.

\section{Materials and Methods}

\section{Plant material}

The dried oleo-gum-resin of B. Serrata (family Burseraceae) was purchased from local Egyptian Herbal Store, Cairo, Egypt. Taxonomical authentication was done by Professor Ibrahim El-Garf professor of Plant Toxonomy, Botany Department, Faculty of Science, Cairo University, Egypt. Voucher specimen was kept in the museum of the Department of Pharmacognosy, Faculty of Pharmacy, Cairo University.

\section{Phytochemical investigation}

Preparation of successive extracts: The powdered oleo-gum-resin of B. Serrata (1000 g) was successively extracted with the following organic solvents: petroleum ether $\left(40-60^{\circ} \mathrm{C}\right)$ (extract 1$)$ and $80 \%$ aqueous methanol (extract 2). In each extract, the solvent was evaporated till dryness under reduced pressure at $40^{\circ} \mathrm{C}$.

Investigation of lipoidal matter: One $\mathrm{g}$ of petroleum ether extract PE (extract 1) was subjected to saponification according to the method reported by Tsuda et al. (1960). The unsaponifiable matter weighed $0.407 \mathrm{~g}$ whereas the fatty acids content weighed $0.098 \mathrm{~g}$. The free fatty acids obtained from saponification were methylated according to the method described by Finar (1967). The constituents of both unsaponifiable and saponifiable fractions were identified using GLC spectrometry by comparing the retention time of their peaks in GLC with those of authentic samples.

Accelerating gradient chromatography of methanol extract of B. Serrata: $1.40 \mathrm{~g}$ of the crude methanol extract ME (extract 2) was dissolved in (400 ml) $\mathrm{MeOH}$ whereas, a white precipitate deposited. This was filtered, purified using sephadex LH-20 (DCM / MeOH, 60:40) and recrystallized from $\mathrm{DCM} / \mathrm{MeOH}$ to afford $30 \mathrm{mg}$ of $\beta$-boswellic acid. This was filtered and the mother liquor was evaporated till dryness to get $0.85 \mathrm{~g}$ of viscous residue. This residue was subjected to silica gel column 
chromatography CC and eluted with n-hexane / DCM / $\mathrm{MeOH}$ gradient. Based on the TLC monitoring, four fractions were obtained: I (100\% DCM), II (30\% DCM/ $\mathrm{MeOH})$, III (50\% DCM/MeOH), and IV (100\% MeOH). GC-MS analysis was done for the chromatographic fractions I,II and III to identify their active chemical compounds.

Preparation of volatile oils: The finely powdered oleo-gum-resin of B. Serrata (100 g) was hydrodistilled using a Likens-Nickerson apparatus (Godefroot et al., 2003) to give pale yellow oil with characteristic odour. The resulting oil was dried over anhydrous sodium sulfate and kept at $10^{\circ} \mathrm{C}$ until analysis.

GC/MS analysis of the volatile oil of B. serrate oleo gum resin was performed using a Thermo Scientific, Trace GC Ultra / ISQ Single Quadrupole MS, TG-5MS fused silica capillary column $(30 \mathrm{~m}, 0.251 \mathrm{~mm}, 0.1 \mathrm{~mm}$ film thickness). For GC/MS detection,an electron ionization system with ionization energy of $70 \mathrm{eV}$ was used, Helium gas was used as the carrier gas at a constant flow rate of $1 \mathrm{~mL} / \mathrm{min}$. The injector and MS transfer line temperature was set at $280^{\circ} \mathrm{C}$. The oven temperature was programmed at an initial temperature $40^{\circ} \mathrm{C}$ (hold $3 \mathrm{~min}$ ) to $280^{\circ} \mathrm{C}$ as a final temperature at an increasing rate of $5^{\circ} \mathrm{C} / \mathrm{min}$ (hold $5 \mathrm{~min}$ ). The quantification of all identified components was investigated using a percent relative peak area. A tentative identification of the compounds was performed based on the comparison of their relative retention time and mass spectra with those of the available database libraries, NIST (Nat. Inst.St. Technol., USA), Wiley (Wiley International, USA), and published data (Adams, 1995). Quantitative determination was carried out on the basis of peak area integration. GLC conditions of the unsaponifiable matter and fatty acids was performed on Hewlett Packard-HP 6890 series, GC system, equipped by flame ionization detector. Nitrogen gas was used as a carrier gas. The analysis of the unsaponifiable matter was performed using capillary column (HP-1 methyl siloxane) and oven temperature at $50^{\circ} \mathrm{C} / 11.7$ minutes from $80-325^{\circ} \mathrm{C}$, injection and detector temperature was $300^{\circ} \mathrm{C}$. The operating conditions for fatty acid methyl ester analysis were capillary column polyethylene glycol (60 $\mathrm{m}$ x $320 \mathrm{~mm}$ ), column temperature was $260^{\circ} \mathrm{C}$. Detector and injection temperature was $280^{\circ} \mathrm{C}$. Oven temperature was from $70-260^{\circ} \mathrm{C}$ with a rate $50^{\circ} \mathrm{C} / 10.5$ minutes. Precoated silica gel 60 GF254 plates (E. Merck) were used for TLC. Solvent systems used for the development of chromatograms were gradient chloroform/methanol and sulfuric acid 5\% as spray reagent was used for detection.

\section{In vitro study}

Cell culture: Human hepatocellular carcinoma cell line (HepG2) and colon cancer cell line (HCT 116) were purchased from Naval American Research Unit (NAMRU), Cairo, Egypt. Cells were propagated in the proper conditions and maintained in RPMI-1640 medium with 1\% L-glutamine (Sigma Chemical Co. St. Louis, MO, USA) and supplemented with $10 \%$ fetal calf serum for growth and $1 \%$ penicillin/streptomycin (Wexford, Ireland). Then, cells were cultured at $37^{\circ} \mathrm{C}$ and $5 \% \mathrm{CO}_{2}$.

Cytotoxicity screening: The cytotoxic effect of extracts, chromatographic fractions and volatile oil of $B$. Serrata oleo gum resin as well as the standard anti-cancer drugs (Doxorubicin and 5-fluorouracil) at concentrations $(0,6.25,12.5,25,50$ and $100 \mu \mathrm{g} / \mathrm{mL})$ on HepG2 and HCT 116 human cancer cell lines was evaluatedusing sulphorhodamine-B (SRB) assay according to the method of Skehan et al. (1990). SRB was purchased from Duchefa-Biochemie (Haarlem, Amsterdam, Netherlands).

Briefly, the cells were seeded in 96 well microtiter plates at a concentration of 5000 cells/well $(100 \mu \mathrm{l} /$ well), then left for cell attachment on the plates for $24 \mathrm{~h}$ in $5 \% \mathrm{CO}_{2}$ at $37^{\circ} \mathrm{C}$. After $24 \mathrm{~h}$, cells were incubated for $48 \mathrm{~h}$ with various concentrations of standard anti-cancer drugs or the tested plant extracts, fractions or volatile oils $(0,6.25,12.5,25,50$ and $100 \mu \mathrm{g} / \mathrm{mL})$. Following $48 \mathrm{~h}$ treatment, the media were discarded and the cells were fixed with $10 \%$ trichloroacetic acid (TCA) $150 \mu \mathrm{l} /$ well for $1 \mathrm{~h}$ at $4^{\circ} \mathrm{C}$ (TCA reduce SRB protein binding). Then, the cells were washed with distilled water 3 times. After that, wells were stained for 10-30 min at room temperature with $50 \mu \mathrm{L}$ of $0.4 \%$ SRB dissolved in $1 \%$ acetic acid media $(70 \mu \mathrm{l} /$ well $)$ and kept in dark place. After incubation, the SRB solution was poured off and the plates were washed with $1 \%$ acetic acid to remove unbound dye, until only the cells adhered dye were left. Then, the plates were air dried ( $24 \mathrm{~h}$, not exposed to UV). The dye was solubilized with $150 \mu \mathrm{l} /$ well of $10 \mathrm{mM}$ tris base solution (PH 7.4), and the mixture was shaken for 5 min at at room temperature $\left(25 \pm 2^{\circ} \mathrm{C}\right)$. The optical density (OD) of each well was measured spectrophotometrically at 545 and $540 \mathrm{~nm}$ with an ELISA microplate reader. The experiment was performed in triplicate and the percentages of cell viability were calculated. Finally, the $\mathrm{IC}_{50}$ values, the concentrations which inhibit $50 \%$ of cell viability, were obtained by plotting the percentages of cell viability versus the concentrations of the tested plant materials using sigmoidal concentration-response curve fitting models (Sigmaplot software).

Measurement of cellular protein content: The method described here has been optimized for the detection of cellularprotein content as a consequence of treatment with the tested plant materials using SRB assay. Its principle is based on the ability of the protein dye SRB to bind electrostatically and $\mathrm{pH}$ dependent on protein basic amino acid residues of TCA-fixed cells. After an incubation period $(24 \mathrm{~h})$, cell monolayers were fixed with $10 \%$ (wt/ vol) TCA and stained with SRB for $30 \mathrm{~min}$, after which the excess dye is removed by washing repeatedly with $1 \%$ ( $\mathrm{vol} / \mathrm{vol}$ ) acetic acid. The protein-bound dye was dissolved in 10 mMTris base solution for OD determination at 510 $\mathrm{nm}$ using a microplate reader. The results are linear over a 20-fold range of cell numbers and the sensitivity was comparable to those of the fluorometric methods.

\section{Statistical analysis}

The present results were expressed as mean of three independent experiments \pm the standard deviation (SD). One way analysis of variance (ANOVA) was used for analysis of results at the significance level of p-value $<0.05$ (Armitage and Berry, 1987). 


\section{Results}

\section{Phytochemical Analyses}

Table (1) illustrated the summary of the obtained materials derived from $B$. serrate oleo gum resin as a consequence of extraction, fractionation and hydrodistillation. These tested plant materials are subjected to the in vitro cytotoxicity study on HepG2 and HCT 116 cell lines.

GLC of the lipoidal matter: The unsaponifiable matter analyzed by GLC spectrometry showed the presence of eight hydrocarbons $(99.11 \%)$ and three sterols $(0.89 \%)$. GLC of the saponifiable matters, revealed the presence of 13 saturated fatty acids (25.63\%), together with nine unsaturated fatty acids (74.37\%) (Tables 2 and 3 ).

GC/MS analysis of chromatographic fractions: GC/ MS analysis was done for the chromatographic fractions I,II, and III to understand the active chemical compounds present in these fractions. The MS spectra was done for matching in mass bank and the fragmentation pattern of compounds has indicated the presence of pent-2-ene-1,4-dione (RT: 9.18, 14.01\%), 2-methyllevulinic acid methyl easter (RT:13.57, 65.20\%), 3,5dimethyl- 1- hexane (RT:16.10, 3.25\%) and methyl,14methylpentadecanoate(RT:42.32, 15.14\%) in fraction I. However, the fragmentation pattern of fraction II showed the presence of 1,1- dimethoxy cyclohexane (RT:13.52, $32.20 \%$ ), 1-methoxy-4-(1-propenyl)benzene(RT:20.72, $31.04 \%$ ) and 17a-hydroxy-17a-cyano,Preg-4-en-3-one (RT: $43.27,34.24 \%$ ). The same compounds were mostly present in fraction III.

GC/MS analysis of the volatile oils: The yield of the volatile oils of $B$. serrate oleo gum resin was $2.7 \%$. The GC/MS chromatogram of the hydrodistillate revealed the presence of 8 monoterpenes and 3 sesquiterpenes (Figure 1) with a total concentration of the identified compounds 93\% (Table 4).

\section{Cytotoxic activity against HepG2 cell line}

The cytotoxicity effect of each plant derived material under study and the standard anti-cancer drug, DOX, on hepatoma cell line (HepG2) was investigated at concentrations $(0,6.25,12.5,25,50$ and $100 \mu \mathrm{g} / \mathrm{mL})$ using SRB assay. Data in Figure 2 illustrated the percentage of viability of HepG2 cells after 48h from treatment with different concentrations of $B$. Serrata derived materials versus the controls. The present data revealed that the treatment of HepG2 cells with $6.25 \mu \mathrm{g} / \mathrm{mL}$ of DOX significantly $(\mathrm{P}<0.05)$ decreased cell viability to $66.43 \%$ whereas cells treated with 12.5 and $25 \mu \mathrm{g} / \mathrm{mL}$ of DOX showed significant $(\mathrm{P}<0.05)$ decrease in cell viability to
$58.87 \%$ and $54.80 \%$ respectively. Furthermore, treatment of HepG2 cells with 50 and $100 \mu \mathrm{g} / \mathrm{mL}$ of DOX elicited significant $(\mathrm{P}<0.05)$ decrease in cell viability to $48.77 \%$ and $45.83 \%$ respectively (Figure $2 \mathrm{~A}$ ). The $\mathrm{IC}_{50}$ value for DOX on HepG2 cell line equals $4.68 \mu \mathrm{g} / \mathrm{mL}$ at $48 \mathrm{~h}$ (Table 5).

Treatment of HepG2 cells with $6.25 \mu \mathrm{g} / \mathrm{mL}$ of extract 1 significantly $(\mathrm{P}<0.05)$ decreased cell viability to $8.48 \%$ while treatment with 12.5 and $25 \mu \mathrm{g} / \mathrm{mL}$ of extract 1 induced significant $(\mathrm{P}<0.05)$ decrease in cell viability to $4.60 \%$ and $4.41 \%$ respectively. Similarly, treatment of HepG2 cells with 50 and $100 \mu \mathrm{g} / \mathrm{mL}$ of extract 1 produced significant $(\mathrm{P}<0.05)$ decrease in cell viability to $4.20 \%$ and $3.12 \%$ respectively (Figure $2 \mathrm{~A}$ ). The $\mathrm{IC}_{50}$ value for extract 1 on HepG2 cell line equals $1.58 \mu \mathrm{g} / \mathrm{mL}$ at $48 \mathrm{~h}$ (Table 5).

On the other hand, $\mathrm{HepG} 2$ cells treated with $6.25,12.5$ or $25 \mu \mathrm{g} / \mathrm{mL}$ of extract 2 showed significant $(\mathrm{P}<0.05)$ decrease in cell viability to $46.75 \%, 11.28 \%$ and $6.90 \%$ respectively. Whereas, treatment of cells with 50 and 100 $\mu \mathrm{g} / \mathrm{mL}$ of extract 2 caused significant $(\mathrm{P}<0.05)$ decline in cell viability to $4.66 \%$ and $3.69 \%$ respectively (Figure 2A). The $\mathrm{IC}_{50}$ value for extract 2 on HepG2 cell line equals $5.82 \mu \mathrm{g} / \mathrm{mL}$ at $48 \mathrm{~h}$ (Table 5).

Treatment of HepG2 cells with $6.25 \mu \mathrm{g} / \mathrm{mL}$ of fraction I significantly $(\mathrm{P}<0.05)$ decreased cell viability to $48.10 \%$ while, cells treated with 12.5 and $25 \mu \mathrm{g} / \mathrm{mL}$ of fraction I experienced significant $(\mathrm{P}<0.05)$ suppression in cell viability to $33.50 \%$ and $7.20 \%$ respectively. Furthermore, treatment of HepG2 cells with 50 and $100 \mu \mathrm{g} / \mathrm{mL}$ of fraction I produced significant $(\mathrm{P}<0.05)$ repression in cell viability to $5.70 \%$ and $3.36 \%$ respectively (Figure $2 \mathrm{~B}$ ). The $\mathrm{IC}_{50}$ value for fraction I on HepG2 cell line equals $6.29 \mu \mathrm{g} / \mathrm{mL}$ at $48 \mathrm{~h}$ (Table 5).

Treatment of HepG2 cells with $6.25 \mu \mathrm{g} / \mathrm{mL}$ of fraction II significantly $(\mathrm{P}<0.05)$ reduced cell viability to $58.57 \%$ whereas treatment with 12.5 and $25 \mu \mathrm{g} / \mathrm{mL}$ of fraction II produced significant $(\mathrm{P}<0.05)$ depletion in cell viability to $38.33 \%$ and $19.90 \%$ respectively. Moreover, treatment of HepG2 cells with 50 and $100 \mu \mathrm{g} / \mathrm{mL}$ of fraction II produced significant $(\mathrm{P}<0.05)$ drop in cell viability to $5.62 \%$ and $3.75 \%$ respectively (Figure $2 \mathrm{~B}$ ). The $\mathrm{IC}_{50}$ value for fraction II on HepG2 cell line equals $8.38 \mu \mathrm{g} / \mathrm{mL}$ at $48 \mathrm{~h}$ (Table 5).

At the same line, HepG2 cells treated with $6.25,12.5$ and $25 \mu \mathrm{g} / \mathrm{mL}$ of fraction III showed significant $(\mathrm{P}<0.05)$ regression in cell viability to $79.64 \%, 52.34 \%$ and $41.16 \%$ respectively. Whereas, treatment of HepG2 cells with 50 and $100 \mu \mathrm{g} / \mathrm{mL}$ of fraction III caused significant $(\mathrm{P}<0.05)$ reduction in cell viability to $31.65 \%$ and $5.38 \%$ respectively (Figure $2 \mathrm{C}$ ). The $\mathrm{IC}_{50}$ value for fraction III on HepG2 cell line equals $17.40 \mu \mathrm{g} / \mathrm{mL}$ at $48 \mathrm{~h}$ (Table 5).

Table 1. Summary of the Obtained Materials of B. Serrate Oleo Gum Resin Subjected to in vitroStudy

\begin{tabular}{ll}
\hline Material & \multicolumn{1}{c}{ Description } \\
\hline Extract 1 & Total petroleum ether extract \\
Extract 2 & Total methanol extract \\
Fraction I & Fractionated from total methanol extract after using 100\% chloroform. \\
Fraction II & Fractionated from total methanol extract after using 7:3 chloroform-MeOH gradient. \\
Fraction III & Fractionated from total methanol extract after using 5:5 chloroform-MeOH gradient. \\
Fraction IV & Fractionated from total methanol extract after using 100\% MeOH. \\
Volatile oils & Total volatile oils \\
\hline
\end{tabular}


Phytochemical Analysis and Anti-cancer Investigation of Boswellia serrata Bioactive Constiteuents in Vitro

On the other hand, HepG 2 cells treated with $6.25,12.5$ and $25 \mu \mathrm{g} / \mathrm{mL}$ of fraction IV showed significant $(\mathrm{P}<0.05)$ decrease in cell viability to $62.20 \%, 24.75 \%$ and $13.33 \%$ respectively. Whereas, treatment of HepG2 cells with 50 and $100 \mu \mathrm{g} / \mathrm{mL}$ of fraction IV caused significant $(\mathrm{P}<0.05)$ decrease in cell viability to $4.72 \%$ and $3.33 \%$ respectively (Figure 2C). The $\mathrm{IC}_{50}$ value for fraction IV on HepG2 cell line equals $7.43 \mu \mathrm{g} / \mathrm{mL}$ at $48 \mathrm{~h}$ (Table 5).

Treatment of HepG2 cells with $6.25 \mu \mathrm{g} / \mathrm{mL}$ of volatile oils significantly $(\mathrm{P}<0.05)$ decreased cell viability to $36.7 \%$ while, treatment with 12.5 and $25 \mu \mathrm{g} / \mathrm{mL}$ of volatile oils showed significant $(\mathrm{P}<0.05)$ decrease in cell viability by $36.6 \%$ and $31.3 \%$ respectively. Likewise, treatment of HepG2 cells with 50 and $100 \mu \mathrm{g} / \mathrm{mL}$ of volatile oils produced significant $(\mathrm{P}<0.05)$ decrease in cell viability to $24.1 \%$ and $21.5 \%$ respectively (Figure $2 \mathrm{D}$ ). The $\mathrm{IC}_{50}$ value for volatile oils on HepG2 cell line equals $5.5 \mu \mathrm{g} / \mathrm{mL}$ at $48 \mathrm{~h}$ (Table 5). These results showed a dose dependent decrease in cell viability of HepG2 cells after treatment with the reference drug, extracts, fractions or volatile oils.

Table 2. GC/MS analysis of unsaponifiable matter of petroleum ether extract of $B$. Serrata oleo gum resin

\begin{tabular}{lcc}
\hline Retention Time & Compound & Composition \% \\
\hline 17.22 & Eicosane & 3.19 \\
17.92 & Heneicosane & 4.61 \\
20.91 & Tricosane & 75.32 \\
21.75 & Tetracosane & 8.47 \\
22.51 & Pentacosane & 2.67 \\
23.34 & Hexacosane & 2.58 \\
24.61 & Octacosane & 1.16 \\
27.91 & Triacontane & 1.11 \\
28.72 & Cholesterol & 0.14 \\
30.07 & Stigmasterol & 0.58 \\
30.73 & $\beta-S i t o s t e r o l$ & 0.17 \\
\hline
\end{tabular}

Table 3. GC/MS Analysis of Fatty Acids Methyl Esters of Petroleum ether Extract of B. Serrata Oleo Gum Resin

\begin{tabular}{|c|c|c|}
\hline Retention Time & \multirow{2}{*}{ Caproic acid (C6:0) } & \multirow{2}{*}{$\frac{\text { Composition } \%}{0.08}$} \\
\hline 6.05 & & \\
\hline 15.06 & Capric acid (C10:0) & 0.51 \\
\hline 18.27 & Lauric acid (C12:0) & 9.38 \\
\hline 19.63 & Tridecanoic acid (C13:0) & 0.68 \\
\hline 21.32 & Myristic acid (C14:0) & 0.32 \\
\hline 22.03 & Myristoleic acid (C14:1) & 9.3 \\
\hline 24.3 & Pentadecanoic acid (C15:0) & 0.51 \\
\hline 28.17 & Palmitic acid (C16:0) & 2.24 \\
\hline 29.38 & Palmitoleic acid (C16:1) & 22.41 \\
\hline 31.62 & Margaric acid (C17:0) & 4.54 \\
\hline 33.1 & Stearic acid (C18:0) & 3.02 \\
\hline 34.79 & Oleic acid (C18:1) & 30.05 \\
\hline 35.41 & Linoleic acid (C18:2) & 3.39 \\
\hline 35.92 & Linolenic acid (C18:3) & 1.61 \\
\hline 40.8 & Arachidic acid (C20:0) & 1.6 \\
\hline 41.23 & 11,14,17-Eicosatrienoic acid (C20:3) & 2.38 \\
\hline 42.05 & Arachidonic acid (C20:4) & 3.2 \\
\hline 44.56 & $\begin{array}{l}\text { 5,8,11,14,17-Eicosapentaenoic acid } \\
\text { (C20:5) }\end{array}$ & 1.91 \\
\hline 45.17 & Heneicosanoic acid (C21:0) & 1.8 \\
\hline 48.55 & Tricosanoic acid (C23:0) & 0.68 \\
\hline 50.36 & Tetracosanoic acid (C24:0) & 0.27 \\
\hline 51.35 & Nervonic acid (C24:1) & 0.12 \\
\hline
\end{tabular}

Cytotoxic activity against HCT 116 cell line

The cytotoxicity effect of each plant derived material under study and the standard anti-cancer drug, 5-FU, on colon cancer cell line (HCT 116) was investigated at concentrations $(0,6.25,12.5,25,50$ and $100 \mu \mathrm{g} / \mathrm{mL})$ using SRB assay. Data in Figure 3 represented the percentage of viability of HCT 116 cells after $48 \mathrm{~h}$ from treatment with different concentrations of the B. Serrata derived materials versus the controls. The current data showed that the treatment of HCT 116 cells with 6.25 and $12.5 \mu \mathrm{g} /$ mL of 5-FU significantly $(\mathrm{P}<0.05)$ decreased cell viability to $69.62 \%$ and $64 \%$ respectively. Whereas, cells treated with 25,50 and $100 \mu \mathrm{g} / \mathrm{mL}$ of 5-FU showed significant $(\mathrm{P}<0.05)$ decrease in cell viability to $57.87 \%, 57.37 \%$ and $53.37 \%$ respectively (Figure $3 \mathrm{~A}$ ). The $\mathrm{IC}_{50}$ value for $5-\mathrm{Fu}$ on HCT 116 cell line equals $3.43 \mu \mathrm{g} / \mathrm{mL}$ at $48 \mathrm{~h}$ (Table 5).

Treatment of HCT 116 cells with $6.25 \mu \mathrm{g} / \mathrm{mL}$ of extract 1 significantly $(\mathrm{P}<0.05)$ decreased cell viability to $14.04 \%$ while treatment with 12.5 and $25 \mu \mathrm{g} / \mathrm{mL}$ of extract 1 produced significant $(\mathrm{P}<0.05)$ suppression in cell viability to $13.11 \%$ and $11.91 \%$ respectively. Likewise, treatment of HCT 116 cells with 50 and $100 \mu \mathrm{g} / \mathrm{mL}$ of extract 1 produced significant $(\mathrm{P}<0.05)$ reduction in cell
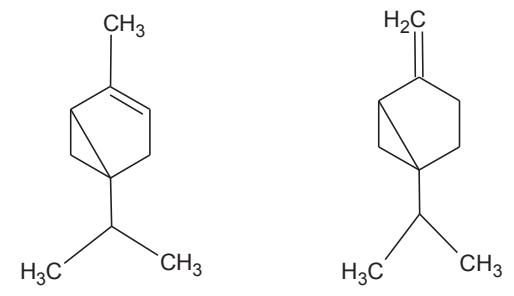<smiles>CC1=CCC(O)(C(C)C)CC1</smiles>

alpha-Thujene<smiles>C=CCC1CC=C(C)[C@H](O)C1</smiles>

Sabinene

Terpinen-4-ol<smiles>CC1=CC(=O)C(C(C)C)CC1</smiles><smiles>C=CC(C)(O)CCC=C(C)C</smiles>

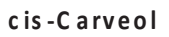<smiles>C=C1CC/C=C(/C)CCC12CC(C)(C)C2</smiles><smiles>C=CCc1cc(OC)c(OC)c(OC)c1</smiles>

Terpinyl acetate beta-C aryophyllene Elemicin<smiles>C=C1C(O)CC2C3CCC(C)(CC[C@@H]3C(C)C)C12</smiles>

beta- Copaen-4-alpha-ol

Germacrene D

Figure 1. Compounds of Volatile Oils of B. Serrata oleo gum resin 

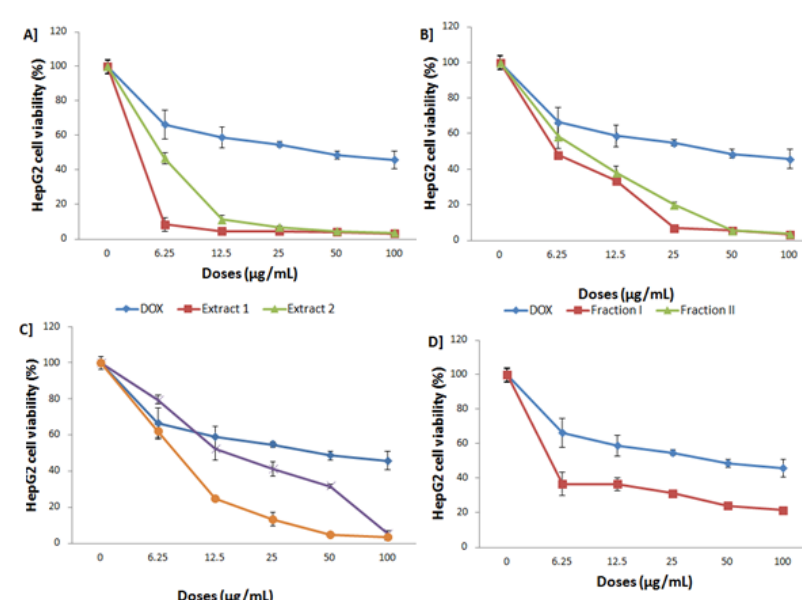

$\rightarrow$ Doses ( $($ g $/ \mathrm{mL}$

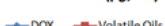

Figure 2. Cytotoxic Effect of $\boldsymbol{B}$. Serrata derived materials on HepG2 cell line

Table 4. GC/MS Analysis of the Volatile Oils of $B$. Serrate Oleogum Resin

\begin{tabular}{llc}
\hline Retention Time & Compound & Composition \% \\
\hline 6.74 & $\alpha$ - Thujene & 1.29 \\
9.13 & Sabinene & 19.11 \\
13.52 & Terpinen-4-ol & 14.64 \\
16.2 & cis-Carveol & 6.26 \\
16.9 & Chavicol & 4.75 \\
18 & Linalool & 1.02 \\
22.37 & Terpinyl acetate & 13.01 \\
24.1 & $\beta$-Caryophyllene & 3.03 \\
31.2 & Elemicin & 7.05 \\
31.43 & $\beta$-Copaen-4- $\alpha-o l$ & 10.24 \\
37.13 & Germacrene D & 12.6 \\
& Total identified & 93 \\
& Total unidentified & 7 \\
\hline
\end{tabular}

Table 5. Cytotoxic Activity $\left(\mathrm{IC}_{50}\right)$ of the Tested Materials of B. Serrata Oleo Gum Resin and the Standard Anticancer Drugs Against HepG ${ }_{2}$ and HCT116 Cell Lines

\begin{tabular}{lcc}
\hline Material & $\begin{array}{c}\mathrm{IC}_{50}(\mu \mathrm{g} / \mathrm{ml}) \\
\mathrm{HepG}_{2} \text { cells }\end{array}$ & HCT116 cells \\
\hline DOX & 4.68 & - \\
5 -FU & - & 3.43 \\
Extract 1 & 1.58 & 0.12 \\
Extract 2 & 5.82 & 6.59 \\
Fraction I & 6.29 & 8.3 \\
Fraction II & 8.38 & 14.68 \\
Fraction III & 17.41 & 26.11 \\
Fraction IV & 7.43 & 13.16 \\
Volatile oils & 5.5 & 6.2 \\
\hline
\end{tabular}

viability to $4.62 \%$ and $4.50 \%$ respectively (Figure $3 \mathrm{~A}$ ). The $\mathrm{IC}_{50}$ value extract 1 on HCT 116 cell line equals 0.12 $\mu \mathrm{g} / \mathrm{mL}$ at $48 \mathrm{~h}$ (Table 5).

On the other hand, HCT 116 cells treated with 6.25 , 12.5 and $25 \mu \mathrm{g} / \mathrm{mL}$ of extract 2 showed significant $(\mathrm{P}<0.05)$ decline in cell viability to $55.53 \%, 34.75 \%$ and $17.78 \%$ respectively. Whereas, treatment of HCT 116 cells with 50 and $100 \mu \mathrm{g} / \mathrm{mL}$ of extract 2 caused significant $(\mathrm{P}<0.05)$ decrease in cell viability to $15.50 \%$ and $8.07 \%$ respectively (Figure $3 \mathrm{~A}$ ). The $\mathrm{IC}_{50}$ value extract 2 on HCT 116 cell line equals $6.59 \mu \mathrm{g} / \mathrm{mL}$ at $48 \mathrm{~h}$ (Table 5).

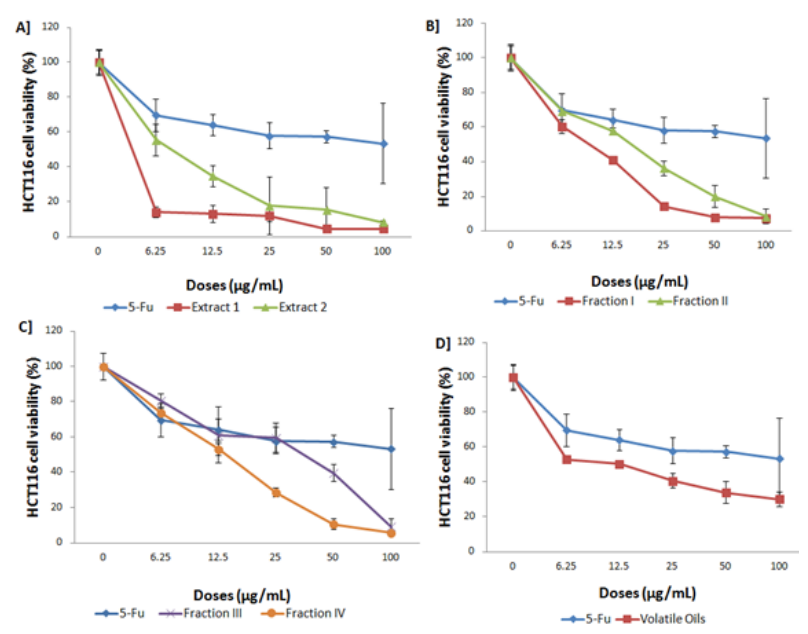

Figure 3. Cytotoxic Effect of $B$. Serrata derived materials on HCT116 cell line

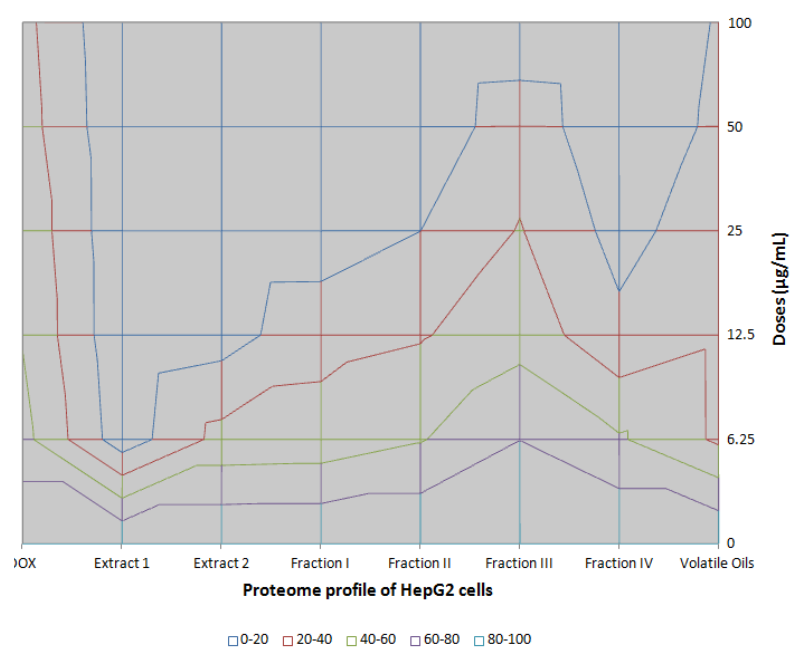

Figure 4. Protein Content of HepG2 Cells after Application of B. Serrata derived $\mathrm{m}$

Treatment of HCT 116 cells with $6.25 \mu \mathrm{g} / \mathrm{mL}$ of fraction I significantly $(\mathrm{P}<0.05)$ decreased cell viability to $60.14 \%$ whereas, HCT 116 cells treated with 12.5 and 25 $\mu \mathrm{g} / \mathrm{mL}$ of fraction I showed significant $(\mathrm{P}<0.05)$ decrease in cell viability to $40.70 \%$ and $14.07 \%$ respectively. Furthermore, treatment of HCT 116 cells with 50 and 100 $\mu \mathrm{g} / \mathrm{mL}$ of fraction I produced significant $(\mathrm{P}<0.05)$ decrease in cell viability to $7.55 \%$ and $7.19 \%$ respectively (Figure 3B). The $\mathrm{IC}_{50}$ value fraction I on HCT 116 cell line equals $8.30 \mu \mathrm{g} / \mathrm{mL}$ at $48 \mathrm{~h}$ (Table 5).

Treatment of HCT 116 cells with $6.25 \mu \mathrm{g} / \mathrm{mL}$ of fraction II significantly $(\mathrm{P}<0.05)$ dropped cell viability to $69.12 \%$ whereas treatment with 12.5 and $25 \mu \mathrm{g} / \mathrm{mL}$ of fraction II showed significant $(\mathrm{P}<0.05)$ decrease in HCT 116 cell viability to $57.64 \%$ and $36.07 \%$ respectively. Moreover, treatment of HCT 116 cells with 50 and 100 $\mu \mathrm{g} / \mathrm{mL}$ of fraction II produced significant $(\mathrm{P}<0.05)$ decline in cell viability to $19.72 \%$ and $8.17 \%$ respectively (Figure 3B). The $\mathrm{IC}_{50}$ value fraction II on HCT 116 cell line equals $14.68 \mu \mathrm{g} / \mathrm{mL}$ at $48 \mathrm{~h}$ (Table 5).

On the same manner, HCT 116 cells treated with 6.25 , 12.5 and $25 \mu \mathrm{g} / \mathrm{mL}$ of fraction III showed significant $(\mathrm{P}<0.05)$ decline in cell viability to $80.72 \%, 61.03 \%$ and $59.49 \%$ respectively. Whereas, treatment of HCT 116 cells 


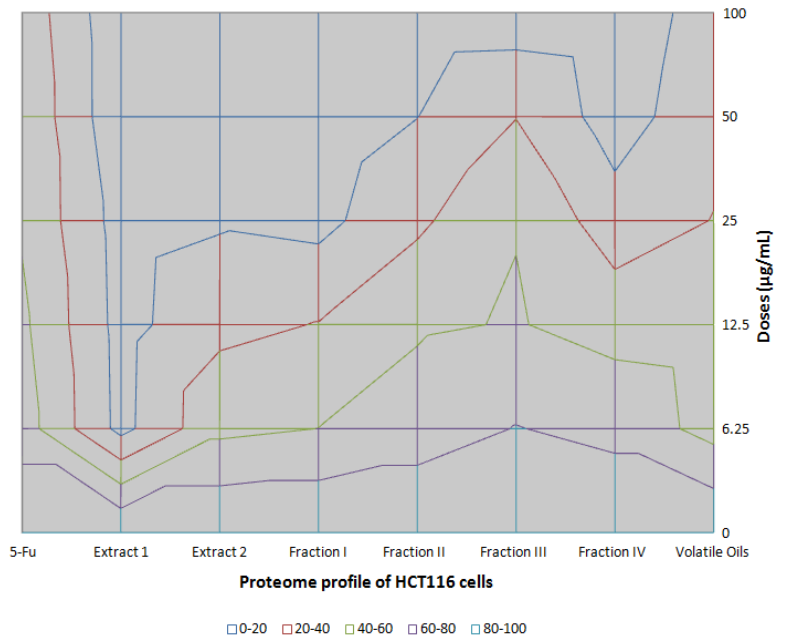

Figure 5. Protein Content of HCT116 Cells After Application of $B$. Serrata derived materials

with 50 and $100 \mu \mathrm{g} / \mathrm{mL}$ of fraction III caused significant $(\mathrm{P}<0.05)$ depletion in cell viability to $39.49 \%$ and $9.16 \%$ respectively (Figure $3 \mathrm{C}$ ). The $\mathrm{IC}_{50}$ value fraction III on HCT 116 cell line equals $26.11 \mu \mathrm{g} / \mathrm{mL}$ at $48 \mathrm{~h}$ (Table 5).

On the other hand, HCT 116 cells treated with 6.25 , 12.5 and $25 \mu \mathrm{g} / \mathrm{mL}$ of fraction IV showed significant $(\mathrm{P}<0.05)$ decrease in cell viability to $73.78 \%, 53.0 \%$ and $28.49 \%$ respectively. Whereas, treatment of cells with 50 and $100 \mu \mathrm{g} / \mathrm{mL}$ of fraction IV caused significant $(\mathrm{P}<0.05)$ regression in cell viability to $10.53 \%$ and $5.62 \%$ respectively (Figure 3C). The $\mathrm{IC}_{50}$ value fraction IV on HCT 116 cell line equals $13.16 \mu \mathrm{g} / \mathrm{mL}$ at $48 \mathrm{~h}$ (Table 5).

Treatment of HCT 116 cells with $6.25 \mu \mathrm{g} / \mathrm{mL}$ of volatile oils significantly $(\mathrm{P}<0.05)$ reduced cell viability to $52.8 \%$ while treatment with 12.5 and $25 \mu \mathrm{g} / \mathrm{mL}$ of volatile oils showed significant $(\mathrm{P}<0.05)$ decrease in cell viability to $50.4 \%$ and $40.6 \%$ respectively. Likewise, treatment of HCT 116 cells with 50 and $100 \mu \mathrm{g} / \mathrm{mL}$ of volatile oils produced significant $(\mathrm{P}<0.05)$ decline in cell viability to $34 \%$ and $30 \%$ respectively (Figure $3 \mathrm{D}$ ). The $\mathrm{IC}_{50}$ value volatile oilson HCT 116 cell line equals $6.2 \mu \mathrm{g} / \mathrm{mL}$ at $48 \mathrm{~h}$ (Table 5). These results showed a dose dependent decrease in cell viability of HCT 116 cells after treatment with the reference drug, extracts, fractions or volatile oils.

\section{Protein content screening}

The effect of $B$. Serrata derived materials on protein content of adherent cells (HepG2 and HCT 116 cells) was investigated. The lower the cellular protein content, the higher the cytotoxic effect of the plant material. This is due to that SRB dye binds to amino acid residues of the TCA-fixed cells. Thus, Our results indicated that extracts 1 and 2, followed by fractions I and IV, and finally volatile oils showed observable decline in cellular protein contents in both HepG2 and HCT 116 cells compared with fractions II and III which showed high cellular protein contents (Figure 4 and 5).

\section{Discussion}

To date, the chemotherapeutic pre-clinical and clinical outputs of B. Serrata oleo gum resin against hepatocellular carcinoma and colon cancer are very limited. GLC analysis of the unsaponifiable fraction of petroleum ether extract of Boswellia serrata revealed the presence of 11 compounds. Hydrocarbon compounds was the major content $(99.11 \%)$ in which tricosane was the major one $(75.32 \%)$ with the presence of octacosane $(1.16 \%)$ and triacontane $(1.11 \%)$. Sterols represented $0.89 \%$ of the total unsaponifiable matter of petroleum ether extract where, they are composed mainly of cholesterol, stigmasterol and $\beta$ - sitosterol. Stigmasterol was the major one $(0.58 \%)$. GLC analysis of fatty acids methyl esters of petroleum ether extract of B. Serrata enabled the identification of 22 fatty acids. Saturated fatty acids represented $25.63 \%$ of the total fatty acids, where lauric acid $(9.38 \%)$ and margaric acid $(4.54 \%)$ were the major saturated fatty acids detected. Unsaturated fatty acids represented $74.37 \%$ of the total fatty acids, where oleic acid (30.05\%) and palmitoleic acid $(22.41 \%)$ were the major unsaturated fatty acids detected.

The data of the current work revealed that doxorubicin produced significant decrease in HepG2 cells viability. This finding means that doxorubicin exhibits significant cytotoxic effect on HepG2 cell line and this could be attributed to its ability to activate c-jun N-terminal kinase (JNK) and CHOP signalling pathways (Panaretakis et al., 2005 and Kim et al., 2006). Turning on these stress pathways activates the proapoptotic B-cell lymphoma 2 (Bcl-2) family protein (Bim) via upregulation of gene expression and/or phosphorylation, leading to mitochondrial cell death (Ley et al., 2005 and Puthalakath et al., 2007).

The results of the current study indicated that total petroleum ether extract (extract 1) produced significant cytotoxic effect on HepG2 cell line. This finding agrees well with that of Demir et al. (2014). Several studies have indicated that phytosterols have tremendous antitumor potential. The anticancer effects of stigmasterol and $\beta$-sitosterol have been studied (Bhagat et al., 2014). Several Polyunsaturated fatty acids have been reported to exhibit cytotoxicity against cancer cells (Hayashi et al., 1998). The high percentage of unsaturated fatty acids in petroleum ether extract of $B$. Serrata supports its high cytotoxic activity (Hayashi et al., 1998). Moreover, the high cytotoxic activity of the petroleum ether extract reported in this study could be credited to the synergism between the unsaturated fatty acids and hydrocarbons together with minor amounts of phytosterols. Moreover several investigations have shown that extraction using polar agents (such as petroleum ether) yields a large number of anti-cancer compounds (Arponsuwan and Punjanon, 2006; Uddin et al., 2009). Furthermore, the mechanism of the cytotoxic effect on HepG2 cell line due to treatment with total petroleum ether extract could possibly ascribed to the capability of sterols to induce cell cycle arrest and apoptosis through mitochondrial dysfunction as reported by Wu et al. (2004).

In the light of the current results, total methanol extract (extract 2) exhibited significant cytotoxic effect on HepG2 cell line. Herein, $1.40 \mathrm{~g}$ of methanolic extract of $B$. Serrata afforded $30 \mathrm{mg}$ of $\beta$-boswellic acid using Sephadex LH-20 column. Liu et al. (2002) reported 
that boswellic acids strongly induce apoptosis through activation of caspase- $3,-8$, and -9 and cleavages of the poly ADP ribose polymerase (PARP) enzyme in hepatoma HepG 2 cells. Moreover, they found that boswellic acids decreased HepG2 cell viability and $[3 \mathrm{H}]$ thymidine incorporation, checked the cells in the G1 phase, and increased percentage of sub-G1. These authors concluded that boswellic acids have anti-proliferation and anti-cancer effects on HepG2 cells. The apoptotic effect of beswellic acids is mediated by a pathway dependent on caspase- 8 activation (Liu et al., 2002). Furthermore, it has been reported that boswellic acids could regulate tumor cell viability by activating a variety of mechanisms. As, they could arrests cancer cells at the G1 phase of cell cycle, suppresses levels of cyclin D1 and E, CDK 2 and 4, and RB phosphorylation, as well as elevates the expression of p21 through a p53-independent pathway (Syrovets et al., 2005 and Liu et al., 2006). Moreover, boswellic acids can activate additional pathways in cancer cells. For example, boswellic acids can inhibit nuclear factor- $\varkappa \mathrm{B}$ and STATs activities in tumor cells (Park et al., 2011 and Kumar et al., 2012).

Boswellia species volatile oils are the most commonly used oils in aromatherapy. Chemical profile of these oils were analyzed and studied for their anti-tumor properties (Suhail et al., 2011). It was reported that B.serrata volatile oils have great potential in natural medicine for cancers (Lin et al., 2012). The GC/MS chromatogram of the volatile oil revealed the presence of a mixture of mono and sesquiterpenes (Sharma et al., 2009). As shown in Table 2, B. serrate volatile oils contains a high proportion of monoterpenes $(67.13 \%)$ in which sabinene (19.11\%),terpinene-4-ol (14.64\%) and terpinyl acetate $(13.00 \%)$ were the major constituents whereas, the remaining was sesquiterpenes $(25.87 \%)$ in which germacrene D $(12.60 \%)$ was the major constituent. While,the minor components are linalool (1.02\%) and $\alpha$-thujene (1.29\%). Our results come in line with the previously reported data with some qualitative and quantitative variations (Pandey et al., 2005; Ali et al., 2008 and Alam et al., 2012).

Recent studies suggested that gum resins of Boswellia species contain active ingredients that have anti-cancer activity (Ni et al., 2012). Volatile oils prepared from the gum resin traditionally used for aromatic therapy has also been shown to have tumor cell-specific anti-proliferative and pro-apoptotic activities. It was demonstrated that Boswellia sacra volatile oils (sesquiterpenes and monoterpenes) has tumor cell-specific cytotoxicity in multiple cancer cell types (Suhail et al., 2011). Results from preliminary clinical observations suggest that Beswellia SP volatile oils may be a valuable therapeutic agent for treating a variety of cancers. These oil sare highly effective in suppressing proliferation and inducing cytoxocity of various pancreatic cancer cell lines; and these in vitro activities correlate with the repression of cell cycle regulators and activation of the caspase pathway (Ni et al. 2012). Consistent with these findings, the results of the in vitro study revealed that volatile oils elicited significant cytotoxic effect on HepG2 cell line.
This effect could be attributed to the presence of mono and sesquiterpenes present in these oil (Ni et al., 2012). It has been reported that $B$. Serrata volatile oils activate arrays of genes and pathways that suppress the growth and induce the apoptosis of established hepatoma cell lines (Lin et al., 2013).

The results of the current study indicated that 5-FU produced significant cytotoxic effect on HCT 116 cell line. This is expected since 5-FU is known to interfere with the metabolism of nucleoside that is incorporated into RNA and DNA. Furthermore, 5-FU inhibits deoxythymidine monophosphate (dTMP) production. Since dTMP is essential for DNA replication and repair, inhibition of its production may cause cell death (Zhang et al., 2008).

The results of the current work revealed that total petroleum ether extract (extract 1) produced significant cytotoxic effect on HCT 116 cell line. This effect could be allied to the sterols present in this extract. Roussi et al. (2005) reported that $7 \beta$-hydroxysitosterol altered cell cycle traverse leading to an accumulation in $\mathrm{S}$ phase, with simultaneous decrease of cells engaged in the G2/M phase in colon cancer cell line (Caco-2). Moreover, $7 \beta$-hydroxysitosterol has been found to enhance DNA fragmentation in these cells (Shah et al., 2009).

The phytochemical study of methanolic extract of $B$. Serrata led to the isolation and identification of $\beta$-boswellic acid. The high cytotoxic activity of the total methanolic extract against HCT 116 cell line could be due to the presence of naturally occurring triterpenoid boswellic acids in the methanolic extract of $B$. Serrata that have anti-carcinogenic and anti-tumor activity (Yazdanpanahi et al., 2014). It was reported that $B$. Serrata extract which contains boswellic acids was more effective at inhibiting cancer cell growth than pure 3-O-acetyl-11-keto-beta-boswellic acid. Boswellic acids have antiproliferative and apoptotic effects on HT29 colon cancer cells (Hostanska et al., 2002). Boswellic acids have been reported to induce apoptosis in cancer cells through activation of pro-apoptotic Bcl-2 family and caspase- 3 and upregulation of cell death receptors such as TNF-related apoptosis-inducing ligand death receptors (DR4) and TNF receptor-1 (TNF-R1) levels, leading to caspase-8 activation (Bhushan et al., 2007). Also, boswellic acids could activate death receptor-5 via upregulation of the expression of CATT/enhancer binding protein homologus protein in human prostate cancer LNCaP and PC-3 cells (Lu et al., 2008).

In the light of the present results, volatile oils of $B$. Serrata elicited significant cytotoxic activity against HCT 116 cell line. This finding could be attributed to the potent growth suppressing effect of these oils on cultured human colon cancer cells. Suhail et al. (2011) found that colonic cancer cells are more sensitive to Boswellia sp. volatile oils with respect to cytotoxicity and apoptosis as compared to their normal counterparts. The growth suppressing activity of $B$. Serrata volatile oils results from a combination of anti-proliferative and pro-apoptotic activities (Frank et al., 2009). In addition, frankincense essential oils overcome multicellular resistance and suppresse invasive phenotypes of human cancer cells (Lu et al., 2008). As 
B. Serrata volatile oils simultaneously modulate the activation of multiple signaling pathways and expression of multiple genes related to negative regulation of cell proliferation and cell cycle progression, as well as positive regulation of apoptosis in human cancer cells. Growing evidences revealed that $B$. Serrata volatile oils upregulate the expression of antiproliferative genes, including interleukin 8 (IL8), dual specificity protein kinase (CLK1), disks large homolog 1 (DLG1), Kruppel-like factor 4 (KLF4), enhancer of filamentation 1 (NEDD9), cyclin dependent kinase inhibitor 1A (CDKN1A), IL1A, IL6 and somatostatin receptor 1 (SSTR1) as well as cell cycle arrest genes, including DNA-damage-inducible transcript 3 (DDIT3), IL8 and CDKNIA in human bladder cancer cells (Frank et al., 2009). Also, it has been demonstrated that B. Serrata volatile oils suppresse the expression of cyclin D1 and cdk4 proteins in human cancer cell lines (Suhail et al., 2011; Ni et al., 2012). This may result in blocking G1/S transition in cell cycle progression in these cells (Quelle et al., 1993; Fahraeus et al., 1996). B. Serrata volatile oils also upregulate a number of genes that are responsible for apoptosis, which include CDKN1A, death effector domain containing 2 (DEDD2), immediate earlr response 3 (IER3), IL6, serine/threonine-protein kinase (SGK), TNF- $\alpha$-induced protein 3 (TNFAIP3), growth arrest and DNA damage 45B (GAD45B), and others in human bladder cancer cells. In addition, expression of a cell survival gene AXL has been found to suppressed by B. Serrata volatile oils (Frank et al., 2009).

GC/MS analysis of chromatographic fractions I, II and III revealed the presence of seven compounds pent-2-ene1,4-dione; 2-methyl- levulinic acid methyl easter; 3,5dimethyl-1- hexane and methyl, 1-methylpentadecanoate in fraction I. However, fractions II and III showed the presence of 1,1- dimethoxy cyclohexane; 1-methoxy4-(1-propenyl) benzene and 17a-hydroxy-17a-cyano, Preg-4-en-3-one. In the current study, the cytotoxic effect of methanol extract chromatographic fractions I, II, III and IV of $B$. Serrata were evaluated for their antitumor activity against HepG2 and HCT 116 cell lines. As the total methanolic extract, fraction IV showed strong anticancer effect as compared to the chromatographic fractions I, II and III.Regarding the cytotoxic effect of fractions I, II and III, this effect might be attributed to increasing toxicity according to the distribution of polar and nonpolar solvents (Huang et al., 2000; Kumar and Pal, 2012).

It is concluded that studies on natural products would define various molecular mechanisms and targets for tumor growth inhibition and apoptosis. In the present study, we succeeded to identify bioactive materials from B. Serrata oleo gum resin. These constituents proved their usefulness as cytotoxic mediators when applied against HepG2 and HCT 116 cell lines. Regarding both HepG2 and HCT 116 cells, the extracts 1 and 2, followed by fractions I and IV, and finally volatile oils have higher cytotoxic activities and lower cellular protein contents compared to fractions II and III. The cytotoxic efficacy of these constituents were comparable to DOX and 5-FU. Extensive in vivo studies are warranted to explore the precise molecular mechanisms of these natural products in bridling hepatocellular carcinoma and colon cancers.

\section{References}

Abd-Rabou AA, Zoheir KM, Ahmed HA (2012). Potential impact of curcumin and taurine on human hepatoma cells using Huh-7 cell line. Clinical Biochem, 45, 1519-21.

Adams RP(1995). Identification of essential oil components by GC/MS. allured publ. Co, carol stream.

Aggarwal BB, Shishodia S (2006). Molecular targets of dietary agents for prevention and therapy of cancer. Biochem Pharmacol, 71, 1397-421.

Alam M, Khan H, Samiullah L, et al (2012). A review on phytochemical and pharmacological studies of kundur (boswellia serrata roxb ex colebr.) -a unani drug. J Applied Pharmaceutical Sci, 2, 148-56.

Ali NAA, Wurster M, Arnold N, et al (2008). Chemical composition and biological activities of essential oils from the oleogum resins of three endemic soqotraen boswellia species, Rec Nat Prod, 2, 6-12.

Ammon HPT, Safayhi H, Mark T, et al (1993). echanism of antiinflammatory actions of curcumine and boswellic acids. $J$ Ethnopharmacol, 38, 105-12.

Armitage P, Berry G (1987). Comparison of several groups. In, statistical method in medical research $2^{\text {nd }}$ Ed. blockwell significant publication, Oxford. pp. 186-213.

Arponsuwan T, Punjanon T (2006). Tumor cellselective antiproliferative effect of the extract from Morindacitrifoliafruits. Phytotherapy Res, 20, 515-7.

Bhagat J, Lobo R, Kumar N, et al (2014). Cytotoxic potential of Anisochiluscarnosus (L.f.) wall and estimation of luteolin content by HPLC. BMC Complement Alternative Med, 14, 421.

Bhushan S, Kumar A, Malik F, et al (2007). A triterpenediol from Boswellia serrata induces apoptosis through both the intrinsic and extrinsic apoptotic pathways in human leukemia HL-60 cells. Apoptosis, 12, 1911-26

Bishayee A (2012). Editorial, recent advances in the prevention and therapy of hepatocellular carcinoma. Current Cancer Drug Targets, 12, 1043-4.

Center MM, Jemal A (2011). International trends in liver cancer incidence rates. Cancer Epidemiol Biomarkers Prevention, 20, 2362-8.

Demîr T, Ozen MO, Hames-Kocabas EE (2015). Antioxidant and cytotoxic activity of Physalisperuviana. Medicinal Plant Research, 4, 30-34.

El-Serag HB, Rudolph KL (2007). Hepatocellular carcinoma, epidemiology and molecular carcinogenesis. Gastroenterol, 132, 2557-76.

Fahraeus R, Paramio JM, Ball KL, et al (1996). Inhibition of pRb phosphorylation and cell-cycle progression by a 20 -residue peptide derived from p16. Curr Biol, 6, 84-91.

Finar IL (1967). Organic chemistry. 5th ed . London, Longmans Green and Co. Ltd, 1, 212.

Frank MB, Yang Q, Osban J, et al (2009). Frankincense oil derived from Boswellia carteriinduces tumor cell specific cytotoxicity. BMC Complement Altern. Med, 9, 6.

Gao J, Xie L, Yang WS (2012). Risk factors of hepatocellular carcinoma current status and perspectives. Asian Pac J Cancer Prev, 13, 743-52.

Godefroot M, Sandra P, Verzele M (1981). New method for quantitative essential oil analysis. J Chrom, 203, 325-35.

Hayashi Y, Nishikawa Y, Mori H, et al (1998). Antitumor activity of (1 OE, 122)-9-hydroxy-10,12-octadecadienoic acid from rice bran. J Fermentat Bioengineer, 86, 149-53.

Hostanska K, Daum G, Saller R (2002). Cytostatic and apoptosisinducing activity of boswellic acids toward malignant cell lines in vitro. Anticancer Res, 22, 2853-62.

Huang MT, Badmaev V, Ding Y, et al (2000). Anti-tumor and 
anti-carcinogenic activities of triterpenoid, $\beta$-boswellic acid. Bio Factors, 13, 225-30.

Kawanishi S, Hiraku Y, Pinlaor S, et al (2006). Oxidative and nitrative DNA damage in animals and patients with inflammatory diseases in relation to inflammation related carcinogenesis. Biological Chemist, 387, 365-72.

Kim SJ, Park KM, Kim N, et al (2006). Doxorubicin prevents endoplasmic reticulum stress-induced apoptosis. Biochem Biophys Res Commun, 339, 463-8.

Kumar A, Shah BA, Singh S, et al (2012). Acyl derivatives of boswellic acids as inhibitors of NF-kB and STATs. Bioorg Med Chem Lett, 22, 431-5.

Kumar MS, Pal AK (2012). Investigation of bioactivity of extracts of marine sponge, spongosoriteshalichondrioides (dendy, 1905) from western coastal areas of India. Asian Pac J Tropical Biomedicine, 1784-9.

Ley R, Ewings KE, Hadfield K, et al (2005). Regulatory phosphorylation of Bim, sorting out the ERK from the JNK. Cell Death Differ., 12(8), 1008-14.

Lin J, Dou J, Xu J, (2012). Chemical composition, antimicrobial and antitumor activities of the essential oils and crude extracts of euphorbia macrorrhiza. Molecules, 17, 5030-9.

Lin HK, Suhail MM, Fung KM, et al (2013). Extraction of biologically active compounds by hydrodistillation of Boswellia species gum resins for anti-cancer therapy. $O A$ Alternat Med, 1, 4.

Liu JJ, Huang B, Hooi SC (2006). Acetyl-keto- $\beta$-boswellic acid inhibits cellular proliferation through a p21-dependent pathway in colon cancer cells. Br J Pharmacol, 148, 1099107.

Liu JJ, Nilsson A, Oredsson S, et al (2002). Boswellic acids trigger apoptosis via a pathway dependent on caspase-8 activation but independent on Fas/Fas ligand interaction in colon cancer HT-29 cells. Carcinogenesis, 23, 2087-93.

Lu M, Xia L, Hua H, et al (2008). Acetyl-keto- $\beta$-boswellic acid induces apoptosis through a death receptor 5-mediated pathway in prostate cancer cells. Cancer Res, 68, 1180-6.

Mitupatum T, Aree K, Kittisenachai S, et al (2015). Hep88 mAb-mediated paraptosis-like apoptosis in HepG2 cells via downstream upregulation and activation of caspase-3, caspase-8 and caspase-9. Asian Pac J Cancer Prev, 16, 1771-9

Ni X, Suhail MM, Yang Q, et al (2012). Frankincense essential oil prepared from hydrodistillation of sacra gum resins induces human pancreatic cancer cell death in cultures and in a xenograft murine model. BMC Complement Altern. Med, 12, 253.

Panaretakis T, Laane E, Pokrovskaja K, et al (2005). Doxorubicin requires the sequential activation of caspase-2, protein kinase Cdelta, and c-Jun NH2-terminal kinase to induce apoptosis. Mol Biol Cell, 16, 3821-31.

Pandey RS, Singh BK, Tripathi YB (2005). Extract of gum resins of Boswellia serrata L. inhibits lipopolysaccharide induced nitric oxide production in rat macrophages along with hypolipidemic property. Indian J Experimental Biol, 43, 509-16.

Park B, Sung B, Yadav VR, et al (2011). Acetyl-11-keto-bboswellic acid suppresses invasion of pancreatic cancer cells through the downregulation of CXCR 4 chemokine receptor expression. Int J Cancer, 129, 23-33.

Park YS, Lee JH, Bondar J, et al (2002). Cytotoxic action of acetyl-11-keto-b-boswellic acid (AKBA) on meningioma cells. Planta Med, 68, 397-401.

Puthalakath H, O'Reilly LA, Gunn P, et al (2007). ER stress triggers apoptosis by activating $\mathrm{BH} 3$-only protein Bim. Cell, 129, 1337-49.

Quelle DE, Ashmun RA, Shurtleff SA, et al (1993).
Overexpression of mouse D-type cyclins accelerates G1 phase in rodent fibroblasts. Genes Dev, 7, 1559-71.

Rang HP, Dale MM, Ritter JM, et al (2003). Book review, pharmacology. London, churchill livingstone. fifth edition.

Roussi S, Winter A, Gosse F, et al (2005). Different apoptotic mechanisms are involved in the antiproliferative effects of $7 \beta$-hydroxysitosterol and $7 \beta$-hydroxycholesterol in human colon cancer cells. Cell Death Differentiat, 12, 128-35.

Safayhi H, Sailer ER (1997). Anti-inflammatory actions of pentacyclictriterpenes. Planta Med, 63, 487-93.

Schnekenburger M, Diederich M (2012). Epigenetics offer new horizons for colorectal cancer prevention. Curr Colorectal Cancer Rep, 8, 66-81.

Shah BA, Qazi GN, Taneja SC (2009). Boswellic acids, a group of medicinally important compounds. Nat Prod Rep, 26, $72-89$

Shahat AA, Alsaid MS, Kotob SE, et al (2015). Significance of rumex vesicarius as anticancer remedy against hepatocellular carcinoma, a proposal-based on experimental animal studies. Asian Pac J Cancer Prev, 16, 4303-10

Shao Y, Ho CT, Chin CK, et al (1998). Inhibitory activity of boswellic acids from Boswellia serrata against human leukemia HL-60 cells in culture. Planta Med, 64, 328-31.

Sharma A, Chhikara S, Ghodekar SN, et al (2009). Phytochemical and pharmacological investigations on boswellia serrate. Phcog Rev, 3, 206-215.

Skehan P, Storeng R, Scudiero D, et al (1990). New colorimetric cytotoxicity assay for anticancer-drug screening. J Natl Cancer Inst, 82, 1107-12.

Suhail MM, Wu W, Cao A, et al (2011). Boswellia sacra essential oil induces tumor cell-specific apoptosis and suppresses tumoraggressiveness in cultured human breast cancer cells. BMC Complement Altern Med, 11, 129.

Syrovets T, Gschwend JE, Buchele B, et al (2005). Inhibition of IkB kinase activity by acetyl-boswellic acids promotes apoptosis in androgen-independent PC-3 prostate cancer cells in vitro and in vivo. J Biol Chem, 280, 6170-80.

Tanaka S, Arii S (2009). Molecularly targeted therapy for hepatocellular carcinoma. Cancer Sci, 100, 1-8.

Thomas MB, Jaffe D, Chotietal MM (2010). Hepatocellular carcinoma, consensus recommendations of the national cancer institute clinical trials planning meeting. Clin Oncol, 28, 3994-4005

Tsuda K, Sakai K, Tanbe K, et al (1960). Isolation of 22-dehydrocholesterol from hypnea japonica. J Am Chem Society, 82, 1442.

Uddin SJ, Grice ID, Tiralongo E (2009). Cytotoxic effects of bangladeshi medicinal plant extracts. evid. based complement. Alternat Med, 111, 1-6.

Watson AJ, Collins PD (2011). Colon cancer, a civilization disorder. Digestive Disease, 29, 222-8.

Winking M, Sarikaya S, Rahmanian A, et al (2000). Boswellic acids inhibit glioma growth, a new treatment option? $J$ Neurooncol, 46, 97-103.

World Cancer Research Fund and American Institute for Cancer Research (1997). Food, nutrition and the prevention of cancer, a global perspective, american institute for cancer research, washington, dc., pp. 1-670.

wu sj, ng lt, chen $\mathrm{CH}$, et al (2004). Antihepatoma activity of Physalisangulata and P. peruviana extracts and their effects on apoptosis in human Hep G2 cells. Life Sci, 74, 2061-73.

Yazdanpanahi N, Behbahani M, Yektaeian A (2014). Effect of boswellia thurifera gum methanol extract on cytotoxicity and P53 gene expression in human breast cancer cell line, Iranian J Pharmaceutical Res, 13, 719-24.

Zhang N, Yin Y, Xu S, et al (2008). 5-Fluorouracil, mechanisms of resistance and reversal strategies. Molecules, 13, 1551-69. 